\title{
Impacts of a Garbage Disposal Facility on the Water Quality of Çavuşlu Stream in Giresun, Turkey: A Health Risk Assessment Study by a Validated ICP-MS Assay
}

\author{
Bayram Yüksel ${ }^{1}$ (D), Fikret Ustaoğlu² (D), Enes Arica ${ }^{3}$ (i)
}

Cite this article as: Yuksel, B., Ustaoglu, F., \& Arica, E. (2021). Impacts of a garbage disposal facility on the water quality of Çavuşlu stream in Giresun, Turkey: A health risk assessment study by a validated ICP-MS assay. Aquatic Sciences and Engineering, 36(4), $181-192$.

ORCID IDs of the author: B.Y. 0000-0001-7686-8648 F.U. 0000-0002-8195-8557 E.A. $0000-0002-8663-4826$

'Giresun University, Espiye Vocational School, Giresun, Turkey

${ }^{2}$ Giresun University, Department of Biology, Giresun, Turkey

${ }^{3}$ Dicle University, Department of Forensic Medicine, Diyarbakır, Turkey

Submitted

22.12.2020

Revision Requested: 11.03.2021

Last Revision Received: 12.04.2021

Accepted:

24.05.2021

Online Published:

27.07.2021

Correspondence:

Fikret Ustaoğlu

E-mail:

fikret.ustaoglu@giresun.edu.tr

(c) Copyright 2021 The Author(s)

Available online at

https://dergipark.org.tr/ase

\begin{abstract}
Environmental concerns have been raised because of a garbage disposal facility (GDF) constructed near Çavuşlu Stream in Giresun, Turkey. This article proposes a fully validated ICP-MS technique to investigate the impacts of the GDF on the water quality of the stream and provide a human health risk estimation. Water sampling was carried out at four different stations and in tap water since the stream is the primary source of drinking water for the inhabitants of the town. Quantification of selected toxic metals ( $\mathrm{As}, \mathrm{Pb}, \mathrm{Cd}, \mathrm{Hg}, \mathrm{Sb}, \mathrm{Al}$, and $\mathrm{Ni}$ ) in conjunction with the essential and other elements ( $\mathrm{Se}, \mathrm{Cu}, \mathrm{Fe}, \mathrm{Mg}, \mathrm{Mn}, \mathrm{Zn}$, and $\mathrm{Co}$ ) was performed by the use of the previously validated ICP-MS method. Once water quality index (WOI), heavy metal pollution index (HPI), and heavy metal evaluation index ( $\mathrm{HEI}$ ) were computed, the health risk assessment was studied according to the US EPA's method. Although the stations (2, 3, 4, and tap water) showed excellent water quality, station-1, which is the closest one to the facility, was classified as poor water quality. Lifetime cancer risk (LCR) was only significant both for adults and children in station-1. In addition, low risk regarding non-carcinogenic health hazards was found for children. The results indicate that the facility decreases the water quality of this stream and is possibly responsible for LCR. In conclusion, the ecological environment and human health should be protected by further monitoring the effect of the GDF on the ecological system.
\end{abstract}

Keywords: ICP-MS, water quality, health risk assessment, toxic metals, industrial pollution

\section{INTRODUCTION}

Ecological pollution is an increasing difficulty all over the world as a result of industrialization, which influences each lifeform (Mutlu et al., 2016; Aydın et al., 2021). In particular, water pollution is one of the most significant issues, since the accessibility of high-quality drinking water is necessary for environmental and human health (Taş \& Şişman, 2020). Nowadays, many water supplies are at risk because of uncontrolled industrialization and urbanization (Küçükosmanoglu \& Filazi, 2020; Egbueri \& Mgbenu, 2020). Hence, pollution is a global complication that affects surface water like rivers and streams (Taş \& Kolören, 2017; Hadi et al., 2019). Continuing the release of heavy metals into surface waters can cause various chemical, physical, and biological problems (Ustaoğlu et al., 2020a). Contamination may originate from anthropogenic and geogenic sources (Ustaoğlu et al., 2017; Ustaoğlu \& Tepe, 2018; Yuksel \& Arica, 2018). Pollution in drinking water sources is associated with organic and inorganic impurities involving heavy metals and chemical ions (Egbueri \& Mgbenu, 2020). In water ecosystems, excess amounts of metals with high persistence in nature are responsible for toxicity, as they can accumulate in aquatic organisms (Mutlu \& Kurnaz, 2018; Ali et al., 2019). 
Exposure to arsenic generally occurs through drinking water supplies polluted by natural, geological, and anthropogenic sources of inorganic arsenic. Today, the limit recommended by the World Health Organization $(\mathrm{WHO})$ is $10 \mu \mathrm{g} / \mathrm{L}(\mathrm{WHO}, 2011)$. Yet, it is likely that millions of individuals are using drinking water with an arsenic concentration above this safety standard. The relationship between the consumption of arsenic-contaminated drinking water and health disorders has been studied all around the world. Hence, arsenic exposure has been linked with certain cancer types such as liver, kidney, bladder, lung, and skin cancers, as well as other medical disorders like adverse effects in pregnancy, neurological disorders, and cardiovascular complaints (Ustaoğlu \& Aydın, 2020; Thakur et al., 2020; Zhang et al., 2018; Yüksel et al., 2018). New technics are used to reduce arsenic concentration to a safe limit in the water treatment process (Zhu et al., 2018). Even so, previous studies proposed the possible toxicity of even low-level arsenic exposure because of its life-long accumulation capability in organisms (Roh et al., 2017; Tsuji et al., 2015).

Lead is a toxic heavy metal, and studies regarding lead exposure in drinking water have been well documented over the past few decades as the number of lead pollution cases has risen (DingQuan et al., 2020). It may distress nearly every body system, but chiefly, the hematologic, gastrointestinal, and nervous systems are affected. Furthermore, children are extra vulnerable to medical disorders due to lead exposure (Bozalan et al., 2019, Yüksel et al., 2016), as it damages children's behavioral and mental health (Redmon et al., 2020; Dórea, 2019).

Investigating the mercury levels in surface water such as rivers and lakes, as well as tap and bottled water, is important in water quality assessment because it is a toxic element having no biological or physiological function in humans. However, it is responsible for different sorts of health problems, such as neuropathological degradation, kidney deficiency, renal system failure, and leukemia (Marinho et al., 2020, Yüksel et al., 2017a).

According to the US EPA, cadmium is another toxic element that has been classified as Group B1 (probable human carcinogen). Cadmium pollution in drinking water occurs because of industrial debris and agricultural fertilizers. Specific examples of health disorders that have possibly been linked with cadmium exposure are renal failure, liver injury, muscle cramps, diarrhea, nausea, and vomiting (ATSDR, 2012; Cai et al., 2019). The permissible limit for cadmium in drinking water is $5.0 \mu \mathrm{g} / \mathrm{L}$, according to the US EPA, EU, and TSE. However, the WHO has established this limit as $3.0 \mu \mathrm{g} / \mathrm{L}(\mathrm{WHO}, 2011)$ since cadmium levels in uncontaminated drinking water are usually below $1.0 \mu \mathrm{g} / \mathrm{L}$.

Certain metals are fundamental for aquatic life and other living organisms. The essential metals may be classified in two groups: micronutrients ( $\mathrm{Cu}, \mathrm{Cr}, \mathrm{Co}, \mathrm{Fe}, \mathrm{Se}, \mathrm{Mn}, \mathrm{Mo}$, and $\mathrm{Zn}$ ) and macronutrients ( $\mathrm{Mg}, \mathrm{Ca}, \mathrm{Na}, \mathrm{S}$, and P). However, elevated concentrations of these metals may exert toxicity by distressing reproduction, biotransformation, and growth in living organisms, including human beings (Gheorghe et al., 2017; Stankovic et al., 2014).

Origin characterization of metals dissolved in river water, as well as computing the proportional participation, is required to ensure environmental safety of aquatic ecosystems (Tepe \& Aydın 2017; Tokatlı et al., 2019; Tokatlı et al., 2020). It is therefore beneficial to employ principal component analysis (PCA), hierarchical cluster analysis (HCA), and Pearson's correlation coefficient (PCC) analysis to assess the source and spread of metals in river waters (Köse et al., 2014; Çiçek et al., 2019; Ustaoğlu, 2020). There are critical activations to monitor the water quality of rivers. For instance, source identification of pollution, determining water quality status, and controlling water pollution are employed for effective water management (Taş et al., 2019; Varol, 2020). Since high-quality freshwater sources have rapidly deteriorated, water quality assessment in Turkey has become a significant issue in recent years. Water quality index (WOl), heavy metal pollution index (HPI), heavy metal evaluation index $(\mathrm{HEI})$, hazard quotient $(\mathrm{HQ})$, hazard index $(\mathrm{HI})$, and carcinogenic risk (CR) are techniques that are widely used in water quality assessment (Ustaoğlu \& Tepe, 2019). Therefore, they play an essential role in water resources management.

Çavuşlu Stream, which flows from northeastern Turkey into the Black Sea, is one of the principal watercourses in the region, as the water needs of the town of Çavuşlu are met by caisson wells in the basin. Çavuşlu Stream, also known as Yalakoda Stream, may be exposed to contamination through industrial, domestic, and medical waste from the GDF located near the stream. No environmental studies of water quality and health risk from the Çavuşlu Stream's water have been performed. Since the GDF is suspected to be the origin of water pollution in the town of Çavuşlu, environmental concerns have been rising day by day. For this reason, the primary objective of this research is to investigate the impact of the GDF on the water quality of Çavuşlu Stream and the human health risk. The complementary tools used in this study are to validate an ICP-MS assay to determine metal levels in stream water in the scope of ISO/IEC 17025 certification, and to address the probable origins of metal pollution through statistical tests such as PCC, PCA, and HCA.

\section{MATERIAL AND METHODS}

\section{Research items and sample preparation}

Sample collection was performed in early May 2020. Sample raw volume was $300 \mathrm{~mL}$. Triple sampling was conducted at four different stations, starting from the closest point to the GDF near Çavuşlu Stream in Görele, Giresun, Turkey (Figure 1). In addition, tap water samples from three different houses in the town were utilized in this study. After $10-\mathrm{mL}$ amounts of the samples were filtered through the Acrodisc ${ }^{\circledR}$ Minispike PTFE membrane with a pore size $0.45 \mu \mathrm{m}$ (Merck, Germany), they were mixed with the same amounts of $8 \%(\mathrm{v} / \mathrm{v})$ nitric acid. Calibration standards, at the concentrations of 1.0, 5.0, 10.0, 25.0, 50.0, and $100.0 \mu \mathrm{g} / \mathrm{L}$, were produced by diluting a multi-element calibration mother solution (VHG LABS, Manchester, NH, USA) with an appropriate amount of $4 \%(\mathrm{~V} / \mathrm{v})$ nitric acid. To avoid any sort of cross-contamination, all glassware (Analitik Kimya, Istanbul, Turkey) was stored in $10.0 \%(v / v)$ nitric acid for 24 hours before the analysis.

\section{Instrumentation}

The metal levels in the water samples were quantified utilizing an ICP-MS (7700x ICP-MS, Agilent Corporation, USA). The generation of ultrapure water with a resistivity of $18 \mathrm{M} \Omega \mathrm{cm}$ was provided 


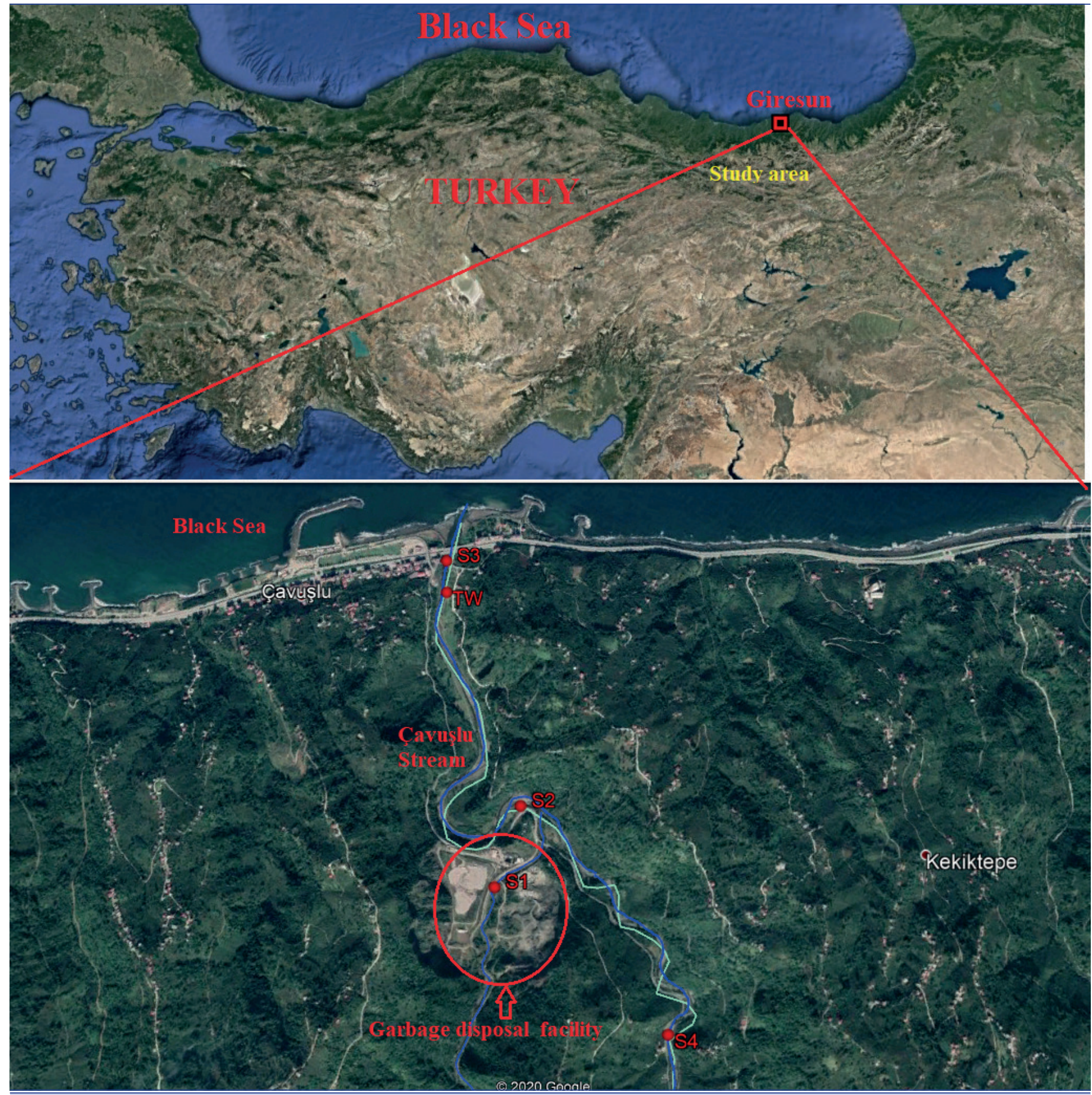

Figure 1. Map of Çavuşlu Town, located in Görele, Giresun, Turkey (The garbage disposal facility and sampling stations are labeled).

for the sample preparation step employing Direct-Q8 (Merck-Millipore, Germany). The operating parameters of the instrument were set as follows: The water specimens were injected (60 s, 0.3 rps) by means of a Meinhard ${ }^{\circledR}$ nebulizer as well as a chilled spray chamber. The autosampler was promptly established to rest in the sampling stand for the specified time, and no flow injection valve was employed. As for the argon gas plasma conditions, reflected power and forward power were $7 \mathrm{~W}$ and $1300 \mathrm{~W}$, respectively. The gas flow rates of plasma, auxiliary, and nebulizerwere set at 16.0, 1.0, and 1.0 L/min, respectively. Next, nickel interface cones were utilized. The peak jumping mode was employed when running the instrument. The autosampler pump was cleaned between injections in three steps, as follows: i) washing with ultrapure water for 30 seconds, ii) rinsing with $2 \%$ $(\mathrm{v} / \mathrm{v})$ nitric acid for 50 seconds, and iii) concluding the cleaning by using ultrapure water for 50 seconds. 


\section{Standard solutions and reagents}

To plot the calibration graphs, VHG LABS (Manchester, NH, USA) multi-element standards solutions at the concentration of 10 $\mathrm{mg} / \mathrm{L}$ of each element were employed. The internal standard multi-element stock solution to control the quantification stability of the instrument was obtained from Agilent ${ }^{\circledR}$ (USA). Nitric acid $\left(\mathrm{HNO}_{3}, 65 \%\right.$ v/v) was purchased from Merck (Darmstadt, Germany) to prepare calibration standards and sample solutions. The certified reference material (CRM), ERM ${ }^{\circledR}$-CA713 (Sigma-Aldrich, Germany), was utilized to test the validation of the assay. Finally, argon gas with an analytical purity (99.999\%) was obtained from a local supplier in Turkey.

\section{Assay optimization}

As was well documented in our previous paper (Yüksel \& Arica, 2018), quantification of trace element levels in natural water subjects is challenging with the matrix elements ( $\mathrm{Na}, \mathrm{Mg}, \mathrm{Ca}, \mathrm{K}$, and $\mathrm{Cl}$ ) in water. Thus, the water specimens were diluted by the amount of $10 \mathrm{~mL} 8 \%(\mathrm{v}: \mathrm{v})$ nitric acid to weaken the matrix effects. The most favorable signal intensity throughout multi-element quantification at very low concentrations was achieved, employing the three elements ${ }^{7} \mathrm{Li}$ at low mass, ${ }^{89} \mathrm{Y}$ at medium mass, and ${ }^{205} \mathrm{Tl}$ at high mass.

\section{Validation}

Having taken into account the validation guide of the ISO/IEC 17025 standard (Gisbert Albaga et al., 2017), CRM ERM-CA713 Waste Water (Sigma-Aldrich, Taufkirchen, Germany) was analyzed 11 times to validate the assay based on accuracy, precision, recovery, and limit of detection. To improve the validation study, an inhouse secondary reference standard solution at the concentration of $100 \mu \mathrm{g} / \mathrm{L}$ was produced by diluting the multi-element calibration mother solution with an appropriate amount of $4 \%(v: v)$ nitric acid. As described in previous papers, precision was calculated in terms of the coefficient of variation, while accuracy was expressed by relative error (Yüksel et al. 2020; Arica et al. 2018; Horwitz, 1982).
The results of the validation study are given in Table 1, demonstrating that the assay is accurate and precise.

\section{Statistical analysis}

The use of different statistical approaches evaluated elemental quantifications in water samples. The PCC analysis was employed to assess the association between metals and their probable origin. Next, HCA was utilized to interpret the correlation among metals. Finally, PCA was employed to decrease data sets and uncover novel factors. SPSS ${ }^{\circledR}$ software version 22.0 was used throughout the statistical analysis.

\section{RESULTS AND DISCUSSION}

\section{Quantification of metal levels}

Metal levels in aquatic specimens can be measured by various techniques. However, ICP-MS is one of the most widely used assays because of its multi-element analysis capability (Yüksel \& Arica, 2018). Most environmental research does not provide sufficient information regarding the accuracy of the method utilized. The ICP-MS method was validated with respect to accuracy and precision before the determination of metal levels in water samples, which improved the significance of this study. In this research, certified reference material and in-house secondary reference standard solutions were employed to perform the validation procedure. As a result, relative error, the variation of coefficient, and recovery were calculated between $0.5-2.7 \%, 0.9-4.0 \%$, and $97.3-102.4 \%$, confirming that the ICP-MS assay was accurate and precise. Quantified metal concentrations versus WHO, EU, US EPA, and TSE standards are shown in Table 2. Aluminum, iron, and manganese in station-1 exceeded all limits.

Aluminum levels in natural waters may alter dramatically contingent upon numerous mineralogical and physicochemical circumstances. For instance, aluminum levels typically vary between 1.0 to $50 \mu \mathrm{g} / \mathrm{L}$ in water with a neutral $\mathrm{pH}$ value, while they may be as high as 500-1000 $\mathrm{u} / \mathrm{L}$ in increased acidity or organic content

Table 1. Validation Study for the ICP-MS method (Values are given in $\mu \mathrm{g} / \mathrm{L}$ ).

\begin{tabular}{|c|c|c|c|c|c|c|c|}
\hline Metals & Reference Material & Certified Value & Measured Value & RE \% & CV \% & $\mathbf{R} \%$ & LOD \\
\hline $\mathrm{Al}$ & In-House Reference & $100.0 \pm 0.3$ & $98.4 \pm 2.1$ & 1.6 & 2.1 & 98.4 & 1.58 \\
\hline $\mathrm{Sb}$ & In-House Reference & $100.0 \pm 0.1$ & $99.5 \pm 1.6$ & 0.5 & 1.6 & 99.5 & 0.01 \\
\hline As & ERM-CA713 & $10.8 \pm 0.3$ & $11.0 \pm 0.2$ & 1.9 & 1.8 & 101.9 & 0.02 \\
\hline $\mathrm{Cu}$ & ERM-CA713 & $101 \pm 7$ & $100.2 \pm 0.9$ & 0.8 & 0.9 & 99.2 & 0.02 \\
\hline $\mathrm{Hg}$ & ERM-CA713 & $1.84 \pm 0.1$ & $1.79 \pm 0.05$ & 2.7 & 2.8 & 97.3 & 0.01 \\
\hline $\mathrm{Zn}$ & In-House Reference & $100.0 \pm 0.4$ & $101.7 \pm 2.2$ & 1.7 & 2.2 & 101.7 & 0.38 \\
\hline $\mathrm{Fe}$ & ERM-CA713 & $445 \pm 27$ & $451.4 \pm 6.7$ & 1.4 & 1.5 & 101.4 & 5.50 \\
\hline $\mathrm{Cd}$ & ERM-CA713 & $5.09 \pm 0.2$ & $4.97 \pm 0.2$ & 2.4 & 4.0 & 97.6 & 0.02 \\
\hline $\mathrm{Pb}$ & ERM-CA713 & $49.7 \pm 1.7$ & $50.2 \pm 1.1$ & 1.0 & 2.2 & 101.0 & 0.02 \\
\hline $\mathrm{Mn}$ & ERM-CA713 & $95 \pm 4$ & $96.3 \pm 2.2$ & 1.4 & 2.3 & 101.4 & 0.20 \\
\hline $\mathrm{Ni}$ & ERM-CA713 & $50.3 \pm 1.4$ & $49.4 \pm 1.9$ & 1.8 & 3.9 & 98.2 & 0.03 \\
\hline $\mathrm{Se}$ & ERM-CA713 & $4.9 \pm 1.1$ & $5.0 \pm 0.2$ & 2.0 & 4.0 & 102.0 & 0.10 \\
\hline $\mathrm{Ca}$ & In-House Reference & $100.0 \pm 0.5$ & $100.5 \pm 1.9$ & 0.5 & 1.9 & 100.5 & 12.89 \\
\hline $\mathrm{Mg}$ & In-House Reference & $100.0 \pm 0.2$ & $97.9 \pm 3.1$ & 2.1 & 3.2 & 97.9 & 0.05 \\
\hline Co & In-House Reference & $100.0 \pm 0.5$ & $102.4 \pm 2.2$ & 2.4 & 2.2 & 102.4 & 0.01 \\
\hline
\end{tabular}


Table 2. Measured metal concentration versus WHO, EU, US EPA, and TSE standards. Values are given in $\mu \mathrm{g} / \mathrm{L}$.

\begin{tabular}{|c|c|c|c|c|c|c|c|c|c|}
\hline Metals & Station-1 & Station-2 & Station-3 & Station-4 & Tap Water & $\begin{array}{c}\text { WHO, } \\
2011\end{array}$ & EU & USEPA & TSE \\
\hline Aluminum & $1168.33 \pm 15.22$ & $51.34 \pm 1.20$ & $215.33 \pm 2.5$ & $4.32 \pm 0.3$ & $16.80 \pm 0.45$ & 200 & 200 & 200 & 200 \\
\hline Arsenic & $2.86 \pm 0.02$ & $0.79 \pm 0.01$ & $0.14 \pm 0.00$ & $0.49 \pm 0.01$ & $0.23 \pm 0.01$ & 10 & 10 & 10 & 10 \\
\hline Copper & $11.78 \pm 0.13$ & $9.69 \pm 0.13$ & $1.88 \pm 0.01$ & $9.05 \pm 0.01$ & $2.12 \pm 0.02$ & 2000 & 2000 & 1300 & 2000 \\
\hline Mercury & $0.01 \pm 0.00$ & $0.02 \pm 0.00$ & $<L O D$ & $<\mathrm{LOD}$ & $0.01 \pm 0.00$ & 6 & 1 & 2 & 1 \\
\hline Iron & $1273.40 \pm 1.25$ & $85.42 \pm 3.45$ & $88.4 \pm 3.1$ & $176.52 \pm 6.14$ & $2.98 \pm 0.13$ & 200 & 200 & 300 & 200 \\
\hline Cadmium & $1.53 \pm 0.04$ & $1.57 \pm 0.03$ & $0.03 \pm 0.00$ & $1.36 \pm 0.07$ & $0.63 \pm 0.04$ & 3 & 5 & 5 & 5 \\
\hline Lead & $1.78 \pm 0.05$ & $0.28 \pm 0.01$ & $1.36 \pm 0.13$ & $0.92 \pm 0.04$ & $1.28 \pm 0.05$ & 10 & 10 & 15 & 10 \\
\hline Manganese & $150.72 \pm 1.10$ & $60.27 \pm 0.45$ & $3.68 \pm 0.06$ & $2.51 \pm 0.03$ & $1.64 \pm 0.02$ & 50 & 50 & 50 & 50 \\
\hline Nickel & $10.27 \pm 0.26$ & $5.31 \pm 0.07$ & $1.88 \pm 0.01$ & $7.19 \pm 0.12$ & $2.68 \pm 0.04$ & 20 & 20 & .. & 20 \\
\hline Cobalt & $5.12 \pm 0.01$ & $6.27 \pm 0.00$ & $3.3 \pm 0.14$ & $5.97 \pm 0.01$ & $3.46 \pm 0.01$ & 50 & .. & .. &. \\
\hline
\end{tabular}

(Yavuz et al., 2013). Therefore, elevated aluminum concentration in station-1 may be linked with rich organic content that has originated from the GDF.

Iron is an essential element for humans in terms of cellular biochemical processes, as long as its amount is at trace levels. Nevertheless, iron can also become toxic when its concentration is elevated (Yüksel et al., 2017b). Iron concentrations in natural waters are varied between 500 to $50000 \mu \mathrm{g} / \mathrm{L}$, while its levels in drinking water are generally below $300 \mu \mathrm{g} / \mathrm{L}(\mathrm{WHO}, 2011)$. Raised iron levels in station-1 compared to other stations and tap water may be related to high metallic content in the GDF.

Manganese is a naturally rich essential element necessary for many integral biological processes in humans. Manganese concentration in drinking water is usually lower than $100 \mu \mathrm{g} / \mathrm{L}$ while it may be more than $1000 \mu \mathrm{g} / \mathrm{L}$ in freshwater. Drinking water with manganese levels of more than $100 \mu \mathrm{g} / \mathrm{L}$ results in an unpleasant flavor. Although manganese toxicity seldom happens, its level in drinking water should be quantified to avoid toxic exposures (Evans \& Masullo, 2020; WHO, 2011).

Other measured essential metals and toxic metals were not found to be above the maximum contaminant limits. However, toxic metals like arsenic, lead, mercury, and cadmium can have toxic effects even at very low concentrations, as was described in the introduction section.

\section{Water quality index (WOl)}

WOl is one of the best classifying methods computed by taking into account the collective effect of different water quality factors on overall water quality. Therefore, it provides an inclusive and actual perception of the water quality.Initially, WOI was established by Horton (1965) in the USA, and today this approach is broadly benefitted through water quality examiners (Kükrer \& Mutlu, 2019; Ustaoğlu et al., 2020b; Tokatli \& Ustaoğlu 2020). Hence, WQl, in this study, was computed with the formula below (1).

$$
W Q I=\sum\left[W_{i} \times\left(\frac{C_{i}}{S_{i}}\right) \times 100\right] \quad 1
$$

$\mathrm{W}_{\mathrm{i}}=\mathrm{w}_{\mathrm{i}} / \Sigma \mathrm{w}_{\mathrm{i}}$ refers to relative weight. Taking into consideration the comparatively critical impacts of heavy metals on public health, the $W_{i}$ values are designated by minimum and maximum magnitudes of 1 and 5 , respectively. $C_{i}$ represents the microelement level quantified in the water where $\mathrm{Si}$ expresses the reference values reported by WHO (2011) in respect of drinking water. Concerning WOl, water quality is assessed in five categories: WOI $\geq$ 300, undrinkable; $200 \leq \mathrm{WQ} \mid<300$, very poor; $100 \leq \mathrm{WQ} \mid<200$, poor; $50 \leq$ WQl <100, good; WQl $<50$, excellent (Xiao et al., 2019). Assigned weight (AS) and weight relative (WR) are presented in Table 3. Hence, Station-1, which is the closest one to the GDF, showed poor water quality (Table 4).

\begin{tabular}{lcc}
\hline Table 3. & Relative weight of each heavy metal. \\
\hline Metals & Assigned Weight (AW) & Weight Relative (RW) \\
\hline $\mathrm{Al}$ & 4 & 0.073 \\
$\mathrm{Sb}$ & 4 & 0.073 \\
$\mathrm{As}$ & 5 & 0.091 \\
$\mathrm{Cu}$ & 2 & 0.036 \\
$\mathrm{Hg}$ & 5 & 0.091 \\
$\mathrm{Zn}$ & 3 & 0.055 \\
$\mathrm{Fe}$ & 4 & 0.073 \\
$\mathrm{Cd}$ & 5 & 0.091 \\
$\mathrm{~Pb}$ & 5 & 0.091 \\
$\mathrm{Mn}$ & 5 & 0.091 \\
$\mathrm{Ni}$ & 5 & 0.091 \\
$\mathrm{Se}$ & 2 & 0.036 \\
$\mathrm{Ca}$ & 2 & 0.036 \\
$\mathrm{Mg}$ & 2 & 0.036 \\
$\mathrm{Co}$ & 2 & 0.036 \\
& 55 & 1.0
\end{tabular}


Table 4. List of calculated WOl, HPI, and HEI in all stations along with tap water.

\begin{tabular}{lccccc}
\hline & $\begin{array}{c}\text { Sta- } \\
\text { tion-1 }\end{array}$ & $\begin{array}{c}\text { Sta- } \\
\text { tion-2 }\end{array}$ & $\begin{array}{c}\text { Sta- } \\
\text { tion-3 }\end{array}$ & $\begin{array}{c}\text { Sta- } \\
\text { tion-4 }\end{array}$ & $\begin{array}{c}\text { Tap } \\
\text { Water }\end{array}$ \\
\hline WOI & 131.42 & 28.43 & 15.45 & 18.68 & 7.02 \\
$\mathrm{HPI}$ & 38.71 & 29.07 & 5.66 & 20.16 & 10.60 \\
$\mathrm{HEI}$ & 16.91 & 3.40 & 2.14 & 2.08 & 0.76
\end{tabular}

\section{Heavy metal pollution index (HPI)}

Since HPI is a valuation approach considering the united impact of every single heavy metal on total water quality, it has been employed by most scientists to expansively evaluate the overall water quality. $\mathrm{HPI}$, in this study, was calculated with formulas (2 and 3), proposed as follows (Mohan et al., 1996):

$$
\begin{gathered}
H P I=\frac{\sum_{i=1}^{n}\left(Q_{i} W_{i}\right)}{\sum_{i=1}^{n} W_{i}} \\
Q_{i}=\sum_{i=1}^{n} \frac{M_{i}}{S_{i}} \times 100
\end{gathered}
$$

In formulas 2 and 3, Wi expresses the unit weight of the ith factor, Qi refers to the sub-index of the trace-toxic metal, Si states the reference values of the factor, Mi represents the screened values of toxic metals, and $\mathrm{n}$ stands for the number of factors taken into account. When $\mathrm{HPI}<100$, it is, therefore, a low level of heavy metal pollution that is possibly not responsible for severe health effects (Saleh et al., 2018). Apparently, in this study, all stations, along with the tap water, showed $\mathrm{HPI}<100$, which is a low level of heavy metal contamination (Table 4).

\section{Heavy metal evaluation index (HEI)}

Similar to HPI, HEl defines the general trend in the examination of water quality with reference to heavy metal pollution in water. Thereby, it may simply be employed to interpret the pollution degree in water (Edet \& Offiong, 2002). In this study, HEl was computed based on the formula below (4).

$$
H E I=\sum_{i=1}^{n} \frac{H_{C}}{H_{M A C}}
$$

In this formula, $\mathrm{Hc}$ refers to the value detected for every single factor, where $\mathrm{Hmac}$ expresses the magnitude of maximum admissible concentration (MAC) for all variables (WHO, 2011). With reference to MAC, the elevated levels of the metal lead to further unpleasant water quality (Goher et al. 2014). As a general rule, when the level of individual metal exceeds the MAC value ( $\mathrm{HEI}>10)$, the water is not advisable for consumption. The water quality diminishes because of other impacts when metal levels are not exceeding but in the vicinity of the MAC values. Therefore, $\mathrm{HEl}$ is checked out by three classifications as follows: $20<\mathrm{HEl}$ means high contamination, $10<\mathrm{HEl}$ $<20$ means medium contamination, and $\mathrm{HEI}<10$ means low contamination (Saleh et al., 2018). In our study, only station-1 showed medium contamination since it is suspected that the leaking from the GDF contaminates Çavuşlu Stream, whereas other stations and tap water showed low contamination (Table 4). The reason why other stations and tap water have low contamination is possibly the dilution of toxic metals with fresh water in the stream.

\section{Health risk assessment: Hazard quotient, Hazard index, and cancer risk}

Although current health risk assessment approaches, along with the mathematical patterns, may vary in different countries and organizations, the principle employed for this assessment remains the same. Throughout this research, the health risk assessment procedure proposed by the US EPA (2004) was applied. With regard to the trace elements in water, the health risk assessment process was performed by taking into consideration the amount of ingestion along with dermal absorption. To calculate the average daily dose (ADD) as a result of dermal absorption (ADD dermal) and direct digestion (ADD ingestion), the following formulas (5 and 6) offered by the US EPA (2004) were enforced:

$$
\begin{aligned}
& A D D_{\text {ingestion }}=\frac{C_{\text {Water }} \times I R \times A B S_{g} \times E F \times E D}{B W \times A T} \\
& A D D_{\text {dermal }}=\frac{C_{\text {Water }} \times S A \times K_{p} \times E T \times E F \times E D \times C F}{B W \times A T}
\end{aligned}
$$

In these formulas, $A D D_{\text {ingestion }}$ means average daily dose by ingestion and $A D D_{\text {dermal }}$ expresses average daily dose by ingestion in the unit of $\mu \mathrm{g} / \mathrm{kg} /$ day. In addition, $C_{\text {water }}$ refers to the concentration of the metals in surface water in the unit of $\mu \mathrm{g} / \mathrm{L}$. IR is ingestion rate (L/day), which, in our paper, is 2.0 for adult and 0.64 for children. As a parameter, ABSg refers to the unitless gastrointestinal absorption factor. EF is exposure frequency, which is set in our paper at 365 days/year. Next, ED represents exposure length in years, which is set at 70 for adults and 6 for children. BW displays average body weight in the unit of $\mathrm{kg}$, and it was 70 for adults and 20 for children. AT is another parameter expressing the averaging time in days, and it is set in our paper at 25550 and 2190 for adults and children, respectively. SA is a parameter in the formula that stands for exposed skin area in the unit of $\mathrm{cm}^{2}$, and it is 18,000 and 6600 for adults and children, respectively. Where $\mathrm{Kp}$ is the dermal permeability coefficient in water in the unit of $\mathrm{cm} / \mathrm{h}$, ET represents the exposure time throughout shower and bathing, which is $0.6 \mathrm{~h} /$ day in this paper. Finally, CF is the unit conversion factor, which is 1 $\mathrm{L} / 1000 \mathrm{~cm}^{3}$ (Xiao et al., 2019). Values of metals along with toxicological parameters employed for health risk assessment are illustrated in Table 5.

With regard to heavy metals, the non-carcinogenic risk by means of ingestion and dermal absorption was computed, and assessment was performed both for children and adults. As well described in a previous paper (Das et al., 2018), the risk hazard quotient formula (HO) divides the average daily dose (ADD) by reference dose (RfD), while hazard index (HI) refers to the overall quantity of $\mathrm{HQs}$ as well as probable non-carcinogenic effects originatingfrom whole heavy metals. 
Table 5. Hazard quotient and cancer risk for each element of the Çavuşlu Stream.

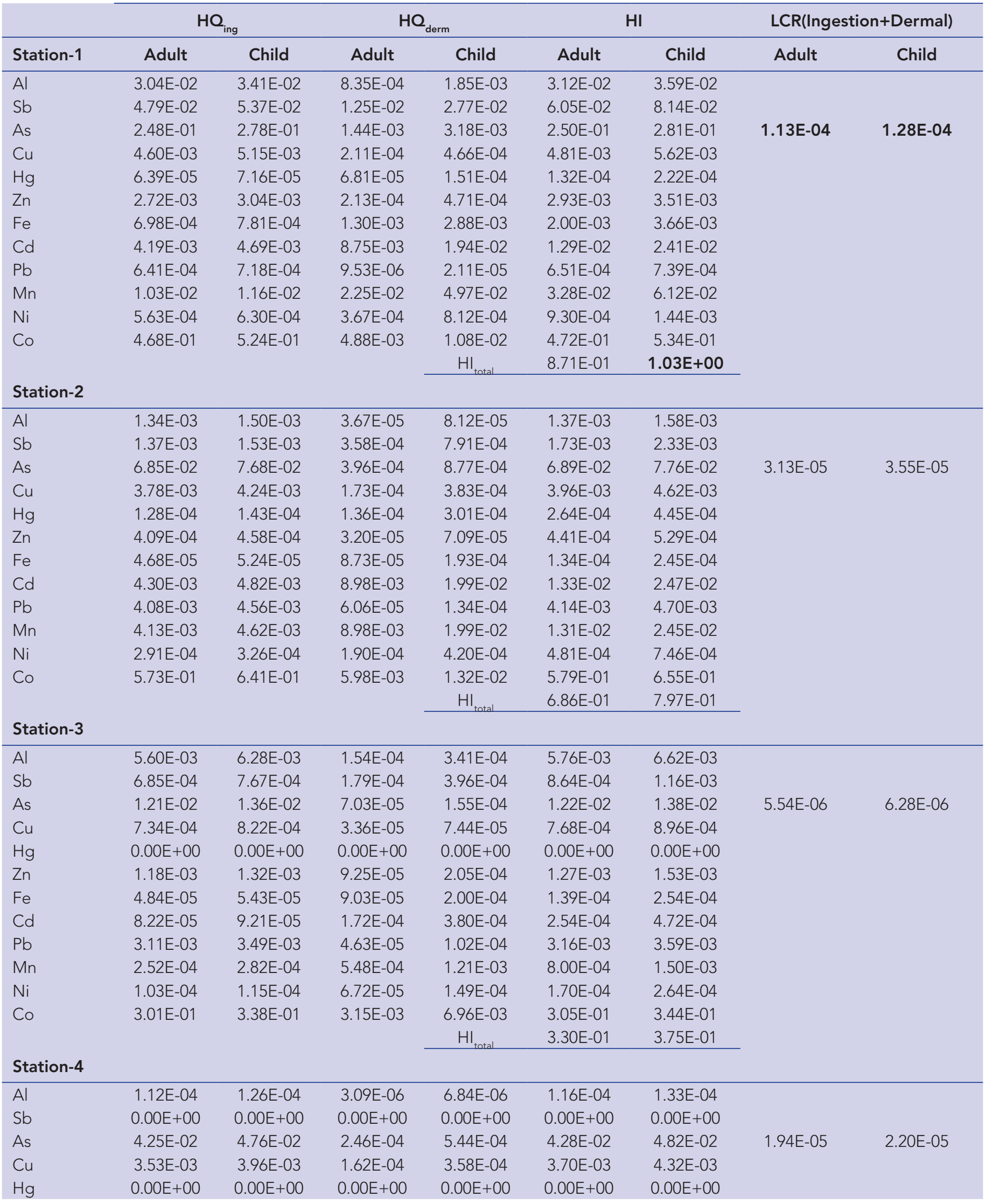




\begin{tabular}{|c|c|c|c|c|c|c|c|c|}
\hline \multicolumn{9}{|c|}{ Station-4 } \\
\hline $\mathrm{Zn}$ & $2.24 \mathrm{E}-03$ & $2.50 \mathrm{E}-03$ & $1.75 \mathrm{E}-04$ & 3.87E-04 & $2.41 \mathrm{E}-03$ & 2.89E-03 & & \\
\hline $\mathrm{Fe}$ & 9.67E-05 & 1.08E-04 & 1.80E-04 & 3.99E-04 & 2.77E-04 & 5.07E-04 & & \\
\hline $\mathrm{Cd}$ & 3.73E-03 & 4.17E-03 & 7.78E-03 & 1.72E-02 & 1.15E-02 & 2.14E-02 & & \\
\hline $\mathrm{Pb}$ & 2.11E-03 & 2.36E-03 & 3.13E-05 & 6.93E-05 & 2.14E-03 & 2.43E-03 & & \\
\hline $\mathrm{Mn}$ & 1.72E-04 & 1.93E-04 & 3.74E-04 & 8.27E-04 & 5.46E-04 & 1.02E-03 & & \\
\hline $\mathrm{Ni}$ & 3.94E-04 & 4.41E-04 & 2.57E-04 & 5.69E-04 & 6.51E-04 & 1.01E-03 & & \\
\hline \multirow[t]{2}{*}{ Co } & 5.45E-01 & 6.11E-01 & 5.69E-03 & 1.26E-02 & 5.51E-01 & 6.23E-01 & & \\
\hline & & & & $\mathrm{HI}_{\text {total }}$ & 6.15E-01 & 7.05E-01 & & \\
\hline \multicolumn{9}{|c|}{ Tap Water } \\
\hline Al & 4.37E-04 & 4.90E-04 & 1.20E-05 & 2.66E-05 & 4.49E-04 & 5.16E-04 & & \\
\hline $\mathrm{Sb}$ & 6.85E-04 & 7.67E-04 & 1.79E-04 & $3.96 \mathrm{E}-04$ & 8.64E-04 & 1.16E-03 & & \\
\hline As & 2.00E-02 & 2.23E-02 & 1.15E-04 & 2.55E-04 & 2.01E-02 & 2.26E-02 & 9.10E-06 & 1.03E-05 \\
\hline $\mathrm{Cu}$ & 8.28E-04 & 9.27E-04 & 3.79E-05 & 8.39E-05 & 8.66E-04 & 1.01E-03 & & \\
\hline $\mathrm{Hg}$ & 6.39E-05 & 7.16E-05 & 6.81E-05 & 1.51E-04 & 1.32E-04 & 2.22E-04 & & \\
\hline $\mathrm{Zn}$ & 1.78E-04 & 2.00E-04 & 1.40E-05 & 3.09E-05 & 1.92E-04 & 2.31E-04 & & \\
\hline $\mathrm{Fe}$ & 1.63E-06 & 1.83E-06 & 3.04E-06 & 6.74E-06 & 4.68E-06 & 8.56E-06 & & \\
\hline $\mathrm{Cd}$ & 1.73E-03 & 1.93E-03 & 3.60E-03 & 7.97E-03 & 5.33E-03 & 9.91E-03 & & \\
\hline $\mathrm{Pb}$ & 2.93E-03 & $3.28 \mathrm{E}-03$ & 4.36E-05 & 9.64E-05 & 2.97E-03 & 3.38E-03 & & \\
\hline $\mathrm{Mn}$ & 1.12E-04 & $1.26 \mathrm{E}-04$ & 2.44E-04 & 5.41E-04 & 3.57E-04 & 6.66E-04 & & \\
\hline $\mathrm{Ni}$ & 1.47E-04 & 1.64E-04 & 9.58E-05 & 2.12E-04 & 2.43E-04 & 3.76E-04 & & \\
\hline \multirow[t]{2}{*}{ Co } & 3.16E-01 & 3.54E-01 & 3.30E-03 & 7.30E-03 & 3.19E-01 & 3.61E-01 & & \\
\hline & & & & $\mathrm{HI}_{\text {total }}$ & $3.51 \mathrm{E}-01$ & 4.01E-01 & & \\
\hline
\end{tabular}

$\mathrm{HQ}$ and $\mathrm{HI}$ were computed based on the following formulas (7 and 8) (US EPA, 2004):

$$
\begin{aligned}
& H Q=\frac{A D D_{\text {ingestion }} / A D D_{\text {dermal }}}{R f D_{\text {ingestion }} / R f D_{\text {dermal }}} \\
& H I=\sum\left(A D D_{\text {ingestion }}+A D D_{\text {dermal }}\right)
\end{aligned}
$$

Medical disorders in humans caused by heavy metals may be observed when $\mathrm{HI}, \mathrm{HQ}>1$. In contrast, no adverse health effect is observed if $\mathrm{HI}, \mathrm{HO}<1$. Wu \& Sun (2016) report that $\mathrm{HI}$ (hazard index) is evaluated in 5 categories: $\mathrm{HI}_{\text {total }}>4$ means extreme risk, $3<\mathrm{HI}_{\text {to- }}$ tal $<4$ means high risk, $2<$ Hltotal $<3$ means medium risk, $1<\mathrm{HI}_{\text {to- }}$ tal $<2$ means low risk, and $\mathrm{HI}_{\text {total }}<1$ means no risk. Therefore, in this paper, low risk in association with non-carcinogenic health hazards was found for children, while no risk was calculated for adults (Table 5).

Lifetime cancer risk (LCR) may be defined as conveying possible risk because of exposure to a carcinogen throughout life, and it was calculated using formula (9) (US EPA, 2004).

$$
L C R=A D D \times C S F
$$

In the present investigation, LCR was assessed due to arsenic content, since it is one of the most carcinogenic toxic metals analyzed. Based on previous articles (Gao et al. 2019; Saha et al. 2017), Cancer Slope Factor (CSF) values were utilized as 0.0015 and $0.00366 \mu \mathrm{g} / \mathrm{kg} /$ day for ingestion and dermal exposure, re- spectively. As reported by the US EPA (2004), the tolerable or acceptable carcinogenic risk ranges from $10^{-6}$ to $10^{-4}$. From another point of view, adverse health effect is very likely by the time $\mathrm{LCR} \geq 10^{-4}$. As can be seen in Table 5, Station-1 has LCR, while other stations and tap water do not show LCR. The reason why station-1 shows poor water quality and LCR may be due to toxic materials leaking from the GDF.

\section{Source identification}

The origin identification was based on hierarchical cluster analysis (HCA) and principal component analysis (PCA) to classify clusters of water quality variables and sampling sites of similar contamination features, as described by Mishra et al. (2017). Therefore, PCA was conducted to associate the contribution source as well as providing consistent evidence through the correlation of metals (Table 6). As evidenced in Figure 2, the component plot in rotated space indicated that metals are linked with three different sources. The outcome from PCA was supported by HCA, signifying sample grouping within the dataset by three clusters (Figure 3). Since sampling stations are in the vicinity of GDF and an agricultural region where pesticides are applied, one of the most significant reasons for toxic metal pollution can be explained as anthropogenic. In addition, it is possible that geogenic contamination has an effect on water quality, as Çavuşlu Stream is also fed from groundwaters.

Pearson's correlation (PC) matrix was employed to observe whether or not metal levels in the stream water are interconnected with one another (Ustaoğlu \& Islam, 2020; Mutlu, 2019). As proposed by Ali et al. (2016), strong interrelation among certain metals in riv- 
Table 6. PCA Component values of metals analyzed.

\begin{tabular}{lccc} 
& \multicolumn{3}{c}{ Components } \\
\hline Variable & PCA1 & PCA2 & PCA3 \\
\hline $\mathrm{Al}$ & .999 & -.007 & .040 \\
$\mathrm{Sb}$ & .987 & .118 & .038 \\
$\mathrm{Fe}$ & .982 & .187 & -.035 \\
$\mathrm{As}$ & .940 & .308 & .131 \\
$\mathrm{Mn}$ & .891 & .285 & .352 \\
$\mathrm{~Pb}$ & -.829 & -.147 & .528 \\
$\mathrm{Ni}$ & .715 & .689 & -.117 \\
$\mathrm{Zn}$ & .700 & .333 & -.532 \\
$\mathrm{Co}$ & .023 & .956 & .188 \\
$\mathrm{Ca}$ & .228 & .940 & -.231 \\
$\mathrm{Cd}$ & .299 & .925 & .208 \\
$\mathrm{Cu}$ & .511 & .833 & .148 \\
$\mathrm{Mg}$ & -.055 & .784 & -.615 \\
$\mathrm{Se}$ & .060 & -.077 & .918 \\
$\mathrm{Hg}$ & .046 & .325 & .871 \\
Eigenvalues & 8.564 & 3.073 & 2.835 \\
\% of variance & 57.095 & 20.487 & 18.897 \\
$\mathrm{Cumulative} \%$ & 57.095 & 77.582 & 96.479
\end{tabular}

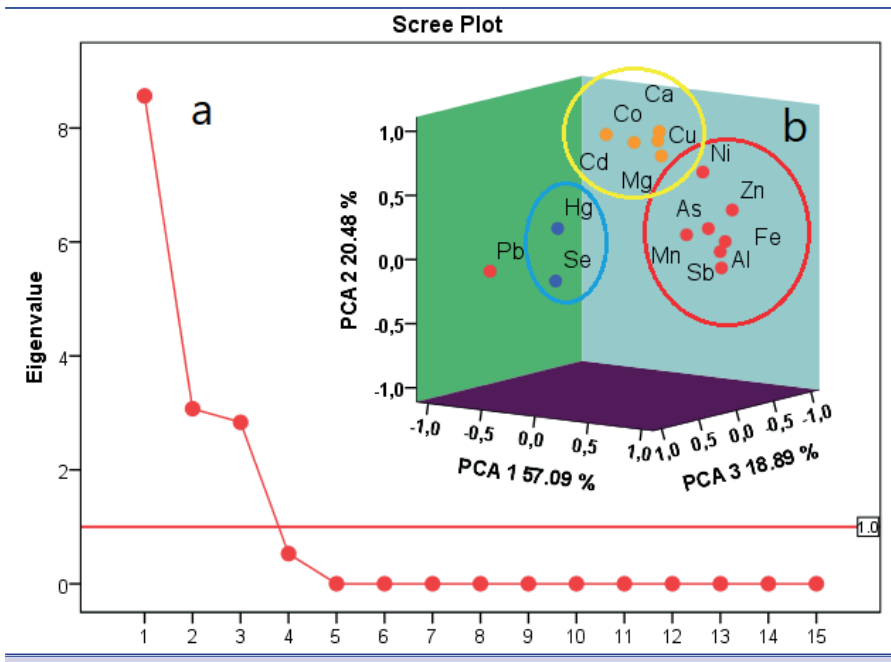

Figure 2. PCA of measured parameters by (a) scree plot of the characteristic roots (Eigen values) and (b) component plot in rotated space.).

Table 7. Correlations of metals.

\begin{tabular}{|c|c|c|c|c|c|c|c|c|c|c|c|c|c|c|c|}
\hline \multicolumn{16}{|c|}{ Correlations } \\
\hline & Al & $\mathrm{Sb}$ & As & $\mathrm{Cu}$ & $\mathrm{Hg}$ & $Z n$ & $\mathrm{Fe}$ & $\mathrm{Cd}$ & $\mathrm{Pb}$ & $M n$ & $\mathrm{Ni}$ & $\mathrm{Se}$ & $\mathrm{Ca}$ & $\mathrm{Mg}$ & Co \\
\hline $\mathrm{Al}$ & 1 & & & & & & & & & & & & & & \\
\hline $\mathrm{Sb}$ & $.986^{\star \star}$ & 1 & & & & & & & & & & & & & \\
\hline As & $.941^{\star}$ & $.976^{\star \star}$ & 1 & & & & & & & & & & & & \\
\hline $\mathrm{Cu}$ & .513 & .595 & .746 & 1 & & & & & & & & & & & \\
\hline $\mathrm{Hg}$ & .074 & .153 & .282 & .369 & 1 & & & & & & & & & & \\
\hline $\mathrm{Zn}$ & .680 & .677 & .667 & .608 & -.448 & 1 & & & & & & & & & \\
\hline $\mathrm{Fe}$ & $.978^{\star *}$ & $.992^{\star \star}$ & $.977^{\star \star}$ & .650 & .082 & .762 & 1 & & & & & & & & \\
\hline $\mathrm{Cd}$ & .299 & .423 & .600 & $.938^{*}$ & .535 & .370 & .461 & 1 & & & & & & & \\
\hline $\mathrm{Pb}$ & -.804 & -.827 & -.763 & -.451 & .332 & -.870 & -.861 & -.287 & 1 & & & & & & \\
\hline $\mathrm{Mn}$ & $.902^{\star}$ & $.930^{\star}$ & $.973^{\star \star}$ & .741 & .451 & .521 & $.916 *$ & .606 & -.597 & 1 & & & & & \\
\hline $\mathrm{Ni}$ & .705 & .781 & .867 & $.925^{\star}$ & .149 & .797 & .834 & .825 & -.753 & .792 & 1 & & & & \\
\hline $\mathrm{Se}$ & .102 & .048 & .127 & .160 & .637 & -.340 & .006 & .096 & .490 & .344 & -.111 & 1 & & & \\
\hline $\mathrm{Ca}$ & .210 & .338 & .480 & .849 & .155 & .557 & .409 & $.901 *$ & -.462 & .393 & .836 & -.312 & 1 & & \\
\hline $\mathrm{Mg}$ & -.086 & .021 & .113 & .523 & -.259 & .526 & .115 & .588 & -.402 & -.041 & .571 & -.654 & 873 & 1 & \\
\hline Co & .027 & .121 & .325 & .870 & .393 & .311 & .191 & $.906^{\star}$ & -.035 & .353 & 657 & .187 & .835 & .616 & 1 \\
\hline
\end{tabular}

er water can be evidence of the same origin of the contamination. The results of the PC matrix are illustrated in Table 7. Mn has a positive correlation with $\mathrm{Al}, \mathrm{Sb}, \mathrm{As}$, and $\mathrm{Fe}$, proposing that these metals in the stream water have similar sources. Furthermore, these findings are consistent with the outcome of PCA and HCA.

\section{CONCLUSION}

For the first time, this paper has outlined the impact of the GDF on the water quality of the Çavuşlu Stream, located in Görele, Gire- sun, Turkey. We also developed a simple revalidation procedure employing in-house and certified reference materials, which resulted in further accurate results after instrumental analysis by ICPMS. Station-1, in the vicinity of GDF, was classified as having poor water quality. Furthermore, LCR was significant only at station-1 both for adults and children, and non-carcinogenic health hazard was estimated only at station-1 for children. Source identification by PCA and HCA indicated that metals in the Çavuşlu Stream might primarily originate from anthropogenic and geogenic sources. Overall, the results point to the GDF decreasing the water 


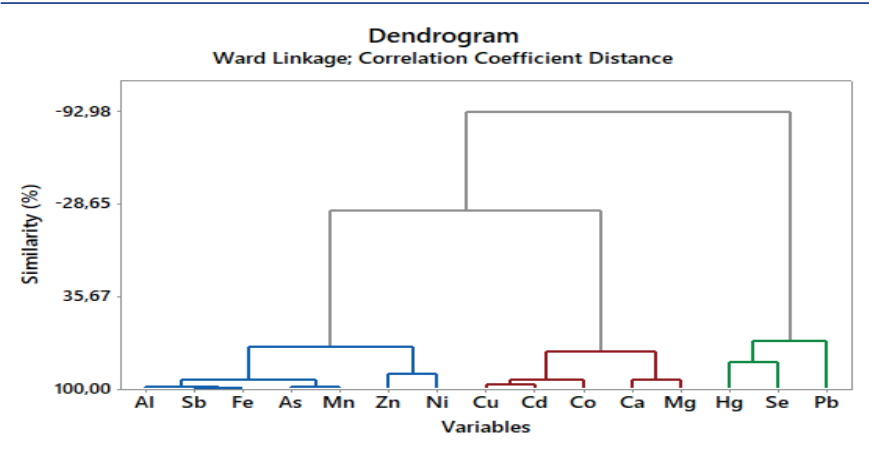

Figure 3. Hierarchical cluster analysis.

quality of the stream and possibly being responsible for LCR. Hence, we propose that the GDF should be moved somewhere else, not in the proximity of water resources and towns. In addition, as a temporary solution, new caisson wells should be constructed on the upper side of the stream where water quality is not directly affected by the GDF. However, the ecological environment and human health will be at risk as long as the activity of the GDF lasts. Environmental monitoring to assess the effect of the GDF on the ecological system should be maintained. Therefore, sediment and fish samples will be investigated to assess ecotoxicological risk in the next phase of this research project.

Conflict of interests: The authors declare that for this article, they have no actual, potential, or perceived conflict of interests.

Ethics committee approval: Ethics committee approval is not required.

\section{Funding: -}

\section{Acknowledgments: -}

\section{Disclosure: -}

\section{REFERENCES}

Ali, H., Khan, E. \& Ilahi, I. (2019). Environmental Chemistry and Ecotoxicology of Hazardous Heavy Metals: Environmental Persistence, Toxicity, and Bioaccumulation. Journal of Chemistry, 1-14. [CrossRef]

Ali, M. M., Ali, M. L., Islam, M. S. \& Rahman, M. Z. (2016). Preliminary assessment of heavy metals in water and sediment of Karnaphuli River, Bangladesh. Environmental Nanotechnology, Monitoring \& Management, 5, 27-35.[CrossRef]

Arica, E., Yuksel, B., Yener, I., Dolak, I., Gok, E. \& Yilmaz, E. (2018). Icp-ms determination of lead levels in autopsy liver samples: an application in forensic medicine. Atomic Spectroscopy, 39(02), 62-66. [CrossRef]

ATSDR. (2012). Toxicological Profile for Cadmium. US Department of Health and Human Services, Public Health Service, Agency for Toxic Substances and Disease Registry

Aydın, H., Ustaoğlu, F., Tepe, Y. \& Soylu, E. N. (2021) Assessment of Water Quality of Streams in northeast Turkey by Water Quality Index and Multiple Statistical Methods. Environmental Forensıcs, [CrossRef]

Bozalan, M., Türksoy, V. A., Yüksel, B., Güvendik, G. \& Söylemezoğlu T. (2019). Preliminary assessment of lead levels in soft plastic toys by flame atomic absorption spectroscopy. Turkish Bulletin of Hygiene and Experimental Biology, 76(3), 243-254. [CrossRef]
Cai, K., Yu, Y., Zhang, M. \& Kim, K. (2019). Concentration, source, and total health risks of cadmium in multiple media in densely populated areas, China. International Journal of Environmental Research and Public Health, 16(13), 2269-2269. [CrossRef]

Çiçek, A., Köse, E. \& Tokatlı, C. (2019). Use of factor analysis to evaluate the sediment quality of a significant mining area: Seydisuyu Stream Basin (Turkey). Polish Journal of Environmental Studies, 28(3), 2021 2025. [CrossRef]

Das, A., Singh, G., Habib, G. \& Kumar, A. (2018). Non-carcinogenic and carcinogenic risk assessment of trace elements of pm2.5 during winter and pre-monsoon seasons in Delhi: a case study. Exposure and Health, 12(1), 63-77. [CrossRef]

Ding-Quan, N. G., Lin, J. K. \& Lin, Y. P. (2020). Lead release in drinking water resulting from galvanic corrosion in three-metal systems consisting of lead, copper and stainless steel. Journal of Hazardous Materials, 398. [CrossRef]

Dórea, J. G. (2019). Environmental exposure to low-level lead (Pb) cooccurring with other neurotoxicants in early life and neurodevelopment of children. Environmental Research, 177. [CrossRef]

Edet, A. E. \& Offiong, O. E. (2002). Evaluation of water quality pollution indices for heavy metal contamination monitoring. a study case from Akpabuyo-Odukpani area, lower cross river basin (southeastern Nigeria). Geojournal, 57(4), 295-304. [CrossRef]

Egbueri, J. C. \& Mgbenu, C. N. (2020). Chemometric analysis for pollution source identification and human health risk assessment of water resources in Ojoto province, southeast Nigeria. Applied Water Science, 10(4). [CrossRef]

Environmental Protection Agency (US EPA). (2004). Risk assessment guidance for superfund volume I human health evaluation manual (Part A). EPA/540/1-89/002. https:// https://www.epa.gov/sites/ production/files/2015-09/documents/rags_a.pdf

Evans, G.R. \& Masullo, L.N. (2020) Manganese Toxicity. In: StatPearls. StatPearls Publishing, Treasure Island (FL). https://www.ncbi.nlm.nih. gov/books/NBK560903/

Gao, B., Gao, L., Gao, J., Xu, D., Wang, Q. \& Sun, K. (2019). Simultaneous evaluations of occurrence and probabilistic human health risk associated with trace elements in typical drinking water sources from major river basins in China. Science of the Total Environment, 666, 139-146. [CrossRef]

Gheorghe, S., Stoica, C., Vasile, G.G., Nita-Lazar, M., Stanescu, E. \& Lucaciu I.E. (2017). Metals toxic effects in aquatic ecosystems: modulators of water quality, Intech. [CrossRef]

Gisbert Algaba, I., Geerts, M., Jennes, M., Coucke, W., Opsteegh, M., Cox, E., Dorny, P., Dierick, K. \& De Craeye, S. (2017). A more sensitive, efficient and ISO 17025 validated Magnetic Capture real time PCR method for the detection of archetypal Toxoplasma gondii strains in meat. International Journal for Parasitology, 47(13), 875-884. [CrossRef]

Goher, M. E., Hassan, A. M., Abdel-Moniem, I. A., Fahmy, A. H. \& Elsayed, S. M. (2014). Evaluation of surface water quality and heavy metal indices of Ismailia Canal, Nile River, Egypt. The Egyptian Journal of Aquatic Research, 40(3), 225-233. [CrossRef]

Hadi, M. P., Fadlillah, L. N., Sih Tifani, A. R. \& Ramdan, V. K. (2019). Heavy Metal Pollution and Water Quality assessment in Belik River Yogyakarta. IOP Conference Series: Earth and Environmental Science, 256(1). [CrossRef]

Horton, R. K. (1965). An index number system for rating water quality. Journal of Water Pollution Control Federation, 37(3), 300-306.

Horwitz, W. (1982). Evaluation of Analytical Methods Used for Regulation of Foods and Drugs. Analytical Chemistry, 54(1), 67A-76A. [CrossRef]

Köse, E., Tokatlı, C. \& Çiçek, A. (2014). Monitoring stream water quality: a statistical evaluation. Polish Journal of Environmental Studies, 23(5), 1637-1647. 
Kucukosmanoglu, A. G. \& Filazi, A. (2020). Investigation of the metal pollution sources in Lake Mogan, Ankara, Turkey. Biological Trace Element Research, 198(1), 269-282. [CrossRef]

Kükrer, S. \& Mutlu, E. (2019). Assessment of surface water quality using water quality index and multivariate statistical analyses in Saraydüzü Dam Lake, Turkey. Environmental Monitoring and Assessment, 191(2), 71. [CrossRef]

Mutlu, E., Kutlu, B. \& Demir, T. 2016. Assessment of Çinarli Stream (HafikSivas) Water Quality via Physico-Chemical Methods, Turkish Journal of Agriculture-Food Science and Technology, 4 (4), 267-278. [CrossRef]

Mutlu, E. \& Kurnaz, A. (2018). Assessment of Physiochemical Parameters and Heavy Metal Pollution in Çeltek Pond Water. Indian Journal of Geo-Marine Sciences, 47(6), 1185-1192.

Mutlu, E. (2019). Evaluation of spatio-temporal variations in water quality of Zerveli Stream (northern Turkey) based on water quality index and multivariate statistical analyses. Environ Monit Assess, 191, 335. [CrossRef]

Marinho, O. R., Lima, M. J. A., \& Reis, B. F. (2020). Automatic multicommuted flow-batch setup for photometric determination of mercury in drinking water at ppb level. Talanta, 206. [CrossRef]

Mishra, S., Kumar, A., Yadav, S. \& Singhal, M. K. (2018). Assessment of heavy metal contamination in water of Kali River using principle component and cluster analysis, India. Sustainable Water Resources Management, 4(3), 573. [CrossRef]

Mohan, S.V., Nithila, P. \& Reddy, S.J. (1996). Estimation of heavy metal in drinking water and development of heavy metal pollution index. $J$ Environ Sci Health Part A 31(2), 283-289. [CrossRef]

Redmon, J. H., Levine, K. E., Aceituno, A. M., Litzenberger, K. \& Gibson, J. M. (2020). Lead in drinking water at North Carolina childcare centers: Piloting a citizen science-based testing strategy. Environmental Research, 183. [CrossRef]

Roh, T., Lynch, C. F., Weyer, P., Wang, K., Kelly, K. M. \& Ludewig, G. (2017). Low-level arsenic exposure from drinking water is associated with prostate cancer in lowa. Environmental Research, 159, 338-343. [CrossRef]

Saha, N., Rahman, M. S., Ahmed, M. B., Zhou, J. L., Ngo, H. H. \& Guo, W. (2017). Industrial metal pollution in water and probabilistic assessment of human health risk. Journal of Environmental Management, 185, 70-78. [CrossRef]

Saleh, H. N., Panahande, M., Yousefi, M., Asghari, F. B., Oliveri, C. G., Talaee, E. \& Mohammadi, A. A. (2019). Carcinogenic and noncarcinogenic risk assessment of heavy metals in groundwater wells in Neyshabur Plain, Iran. Biological Trace Element Research, 190(1), 251-261. [CrossRef]

Stankovic, S., Kalaba, P., \& Stankovic, A. R. (2014). Biota as toxic metal indicators. Environmental Chemistry Letters, 12(1), 63-84. [CrossRef]

Taş, B. \& Kolören, Z. (2017). Evaluation of water qualities of discharging area of some running waters into Black Sea in the Central Black Sea Region of Turkey. Review of Hydrobiology, 10(1), 1-19

Taş, B. \& Şişman H. E. (2020). Assessment of algal diversity and hydrobiological preliminary results in a high-mountain lake (Karagöl Lake, Giresun Mountains, Turkey). Review of Hydrobiology, 13,1-2, 11-38.

Taş, B., Tepe, Y., Ustaoğlu, F. \& Alptekin, S. (2019). Benthic algal diversity and water quality evaluation by biological approach of Turnasuyu Creek, NE Turkey. Desalination and Water Treatment 155, 402-415. [CrossRef]

Tepe, Y. \& Aydin, H. (2017). Water quality assessment of an urban water, Batlama Creek (Giresun), Turkey by applying multivariate statistical techniques. Fresenius Environ Bull, 26, 6413-6420.

Thakur, B. K., Gupta, V., Bhattacharya, P., Islam, M. T. \& Jakariya, M. (2020). Arsenic in drinking water sources in the middle Gangetic Plains in Bihar: an assessment of the depth of wells to ensure safe water supply. Groundwater for Sustainable Development, [CrossRef]
Tokatli, C., Solak, C. N. \& Yilmaz, E. (2020). Water Quality Assessment by Means of Bio-Indication: A Case Study of Ergene River Using Biological Diatom Index. Aquatic Sciences and Engineering, 36(2), 43-51. [CrossRef]

Tokatlı, C., Solak, C. N., Yılmaz, E., Atıcı, T. \& Dayıoğlu, H. (2019). Research into the Epipelic Diatoms of the Meriç and Tunca Rivers and the Application of the Biological Diatom Index in Water Quality. Assessment. Aquatic Sciences and Engineering, 35(1), 19-26. [CrossRef]

Tokatli, C. \& Ustaoğlu, F. (2020). Health risk assessment of toxicants in Meriç River delta wetland, Thrace region, Turkey. Environmental Earth Sciences, 79(18). [CrossRef]

Tsuji, J. S., Garry, M. R., Perez, V. \& Chang, E. T. (2015) Low-level arsenic exposure and developmental neurotoxicity in children: a systematic review and risk assessment. Toxicology, 337, 91-107. [CrossRef]

Ustaoğlu, F. (2020). Ecotoxicological risk assessment and source identification of heavy metals in the surface sediments of Çömlekci Stream, Giresun, Turkey. Environmental Forensics, (2020). [CrossRef]

Ustaoğlu, F., Tepe, Y. \& Aydin, H. (2020a). Heavy metals in sediments of two nearby streams from Southeastern Black Sea coast: Contamination and ecological risk assessment. Environmental Forensics, 21(2), 145-156. [CrossRef]

Ustaoğlu, F., Tepe, Y. \& Taş, B. (2020b). Assessment of stream quality and health risk in a subtropical Turkey river system: a combined approach using statistical analysis and water quality index. Ecological Indicators, 113. [CrossRef]

Ustaoğlu, F., Tepe, Y., Aydın, H. \& Akbaş, A. (2017). Investigation of water quality and pollution level of lower Melet River, Ordu, Turkey. Alınteri Zirai Bilimler Dergisi, 32(1), 69-79. [CrossRef]

Ustaoğlu, F. \& Tepe, Y. (2018). Determination of the sediment quality of Pazarsuyu Stream (Giresun, Turkey) by multivariate statistical methods. Turkish Journal of Agriculture - Food Science and Technology, 6(3),304-312. [CrossRef]

Ustaoğlu, F. \& Tepe, Y. (2019). Water quality and sediment contamination assessment of Pazarsuyu Stream, Turkey using multivariate statistical methods and pollution indicators. Int Soil Water Conserv Res, 7,4756. [CrossRef]

Ustaoğlu, F. \& Aydın, H. (2020). Health risk assessment of dissolved heavy metals in surface water in a subtropical rivers basin system of Giresun (north-eastern Turkey). Desalination and Water Treatment, 194,222234. [CrossRef]

Ustaoğlu, F. \& Islam, S. (2020). Potential toxic elements in sediment of some rivers at Giresun, Northeast Turkey: A preliminary assessment for ecotoxicological status and health risk. Ecological Indicators, 113, 106237. [CrossRef]

WHO (2011). Guidelines for Drinking-Water Quality, 4th ed., Vol. 38, World Health Organization, pp. 1-564, Geneva. [CrossRef]

Wu, J. \& Sun, Z. (2016). Evaluation of shallow groundwater contamination and associated human health risk in an alluvial plain impacted by agricultural and industrial activities, mid-west china. Exposure and Health, 8(3), 311-329. [CrossRef]

Xiao, J., Wang, L., Deng, L. \& Jin, Z. (2019). Characteristics, sources, water quality and health risk assessment of trace elements in river water and well water in the Chinese loess plateau. Science of the Total Environment: Part 2, 650, 2004-2012. [CrossRef]

Varol, M. (2020). Use of water quality index and multivariate statistical methods for the evaluation of water quality of a stream affected by multiple stressors: A case study. Environmental Pollution, 266, 115417. [CrossRef]

Yavuz, C. I., Vaizoğlu, S. A. \& Güler, Ç. (2013.). Aluminium in drinking water. TAF Preventive Medicine Bulletin, 12(5), 589-596. [CrossRef]

Yuksel, B., Kaya, S., Kaya-Akyuzlu, D., Kayaalti, Z. \& Soylemezoglu, T. (2017a). Validation and optimization of an analytical method based on cold vapor atomic absorption spectrometry for the determination 
of mercury in maternal blood, cord blood, and placenta samples. Atomic Spectroscopy, 38(4), 112-116. [CrossRef]

Yuksel, B., Kaya-Akyuzlu, D., Kayaalti, Z., Ozdemir, F., Soylemez-Gokyer, D. \& Soylemezoglu, T. (2017b). Study of blood iron vs. blood lead levels in beta-thalassemia patients in Turkey: an application of analytical toxicology. Atomic Spectroscopy, 38(2), 71-76. [CrossRef]

Yuksel, B. \& Arica, E. (2018). Assessment of toxic, essential, and other metal levels by icp-ms in Lake Eymir and Mogan in Ankara, Turkey: an environmental application. Atomic Spectroscopy, 39(5), 179-184. [CrossRef]

Yuksel, B., Sen, N., Turksoy, V. A., Tutkun, E. \& Soylemezoglu, T. (2018). Effect of exposure time and smoking habit on arsenic levels in biological samples of metal workers in comparison with controls. Marmara Pharmaceutical Journal, 22(2), 218-226. [CrossRef]

Yüksel, B., Kayaalti, Z., Kaya-Akyüzlü, D., Tekin, D. \& Söylemezoglu, T. (2016). Assessment of lead levels in maternal blood samples by graphite furnace atomic absorption spectrometry and influence of maternal blood lead on newborns. Atomic Spectroscopy, 37(3), 114 119. [CrossRef]

Yuksel, B. (2020). Quantitative gc-fid analysis of heroin for seized drugs. Annals of Clinical and Analytical Medicine, 11(1), 38-42. [CrossRef]

Zhang, H., Chang, S., Wang, L. \& Wang, W. (2018). Estimating and comparing the cancer risks from thms and low-level arsenic in drinking water based on disability-adjusted life years. Water Research, 145, 83-93. [CrossRef]

Zhu, N., Qiao, J., Ye, Y. \& Yan, T. (2018). Synthesis of mesoporous bismuthimpregnated aluminum oxide for arsenic removal: adsorption mechanism study and application to a lab-scale column. Journal of Environmental Management, 211, 73-82. [CrossRef] 